Article

\title{
Biophysical Properties of Cultivated Pastures in the Brazilian Savanna Biome: An Analysis in the Spatial-Temporal Domains Based on Ground and Satellite Data
}

\author{
Laerte G. Ferreira $^{1, *}$, Luis E. Fernandez ${ }^{2}$, Edson E. Sano ${ }^{3}$, Chris Field $^{2}$, Silvio B. Sousa ${ }^{1}$, \\ Arielle E. Arantes ${ }^{1}$ and Fernando M. Araújo ${ }^{1}$
}

1 Image Processing and GIS Lab, Federal University of Goiás, UFG-IESA, Campus Samambaia, Cx. Postal 131, Goiânia-GO, 74001-970, Brazil; E-Mails: sousasb@hotmail.com (S.B.S.); arielle_ioiad@hotmail.com (A.E.A.); fernandomsbl@gmail.com (F.M.A.)

2 Department of Global Ecology, Carnegie Institution, Stanford, CA 94305, USA; E-Mails: luisf@stanford.edu (L.E.F.); cfield@ciw.edu (C.F.)

3 Brazilian Agriculture Research Organization (Embrapa Cerrados), Planaltina-DF, 73310-970, Brazil; E-Mail: sano@cpac.embrapa.br

* Author to whom correspondence should be addressed; E-Mail: laerte@iesa.ufg.br; Tel.: +55-62-3521-1096; Fax: +55-62-3521-1077.

Received: 27 November 2012; in revised form: 4 January 2013 / Accepted: 5 January 2013 / Published: 17 January 2013

\begin{abstract}
Brazil has the largest commercial beef cattle herd in the world, with cattle ranching being particularly prominent in the 200-million ha, Brazilian neotropical moist savanna biome, known as Cerrado, one of the world's hotspots for biodiversity conservation. As decreasing productivity is a major concern affecting the Cerrado pasturelands, evaluation of pasture conditions through the determination of biophysical parameters is instrumental for more effective management practices and herd occupation strategies. Within this context, the primary goal of this study was the regional assessment of pasture biophysical properties, through the scaling of wet- and dry-season ground truth data (total biomass, green biomass, and \% green cover) via the combined use of high (Landsat-TM) and moderate (MODIS) spatial resolution vegetation index images. Based on the high correlation found between NDVI (normalized difference vegetation index) and $\%$ green cover $(\mathrm{r}=0.95)$, monthly MODIS-based \% green cover images were derived for the 2009-2010 hydrological cycle, which were able to capture major regional patterns and differences in pasture biophysical responses, including the increasing greenness values towards the southern portions of the biome, due to both local conditions (e.g., more fertile
\end{abstract}


soils) and management practices. These results corroborate the development of biophysically-based landscape degradation indices, in support of improved land use governance and natural area conservation in the Cerrado.

Keywords: pasture monitoring; cerrado biome; vegetation indices; MODIS time series

\section{Introduction}

Brazil has the largest commercial beef cattle herd in the world [1]. It involves the use of approximately 150 million ha of cultivated pastures (mainly Brachiaria species) and is responsible for about $50 \%$ of national total emission of greenhouse gases [2]. Cattle ranching is particularly prominent in the Cerrado, the 200-million ha Brazilian neotropical moist savanna biome, where about $44 \%$ of the Brazilian cattle herd is located $[3,4]$.

The Cerrado, considered one of the world's hotspots for biodiversity conservation [5] and the headwater region of the major rivers of eastern South America, is the main agricultural frontier in the country [6], with nearly $50 \%$ of its original vegetative cover already converted, mostly to pasturelands $[7,8]$. Though instrumental for leveraging Brazil's economic growth during the 70's and early 80's, such large-scale and high-speed conversion has resulted in major environmental modifications, some of which, certainly beyond natural resilience. In particular, the intensive fragmentation of landscapes [9] and replacement of relatively deep-rooted native ecosystems by shallow-rooted grasses have severely affected the original carbon, biogeochemical and water-energy cycles [10].

Declining of pasture productivity, related to aging and overgrazing, is another major concern, which affects at least $50 \%$ of the Cerrado cultivated pastures [11,12]. In addition to widespread environmental impacts associated with the dominance of invading species, pasture degradation increases soil erosion and loss of soil fertility, decreases biomass and soil organic carbon content $[13,14]$, and forces farmers to incorporate new areas of native savanna for their cattle raising activities. About $60 \%$ of clear-cuts detected in the Cerrado during the 2002-2011 time period were triggered by the expansion of adjacent pasture sites established prior to $2002[15,16]$.

Assessing pasture productivity is instrumental for more effective management practices and herd occupation strategies, as well as for the overall evaluation of land use dynamics. Several studies have demonstrated that key degradation indicators, such as the combined proportions of bare soil, non-photosynthetic vegetation (NPV) and photosynthetic vegetation (PV), leaf-area-index (LAI), biomass, and grass density, correlate well with a variety of spectral metrics in the optical domain [17,18]. However, remote sensing based investigations have been mostly focused on small-case study areas. In the Cerrado, in particular, the use of remote sensing imagery has been mainly restricted to mapping pasturelands without further large-scale determination of biophysical parameters or evaluation of pasture conditions.

Within this context, the primary goal and contribution of this study concerns the regional extrapolation of pasture-related biophysical parameters in support of quality assessments at the landscape scale. Specifically, our objectives include: (a) analysis of the biophysical characteristics of the Cerrado cultivated pastures based on field data; (b) sensitivity evaluation of optical vegetation 
indices to ground-based parameters; and (c) scaling of ground truth data based on the synergistic use of high and moderate spatial resolution images.

\section{Experimental Design}

This study encompasses Cerrado areas occupied by planted pasture, as mapped by Sano et al. [8] under the Brazilian project of biodiversity conservation of national biomes-PROBIO [19]. This mapping, based on the analysis of 170 Landsat ETM+ scenes from the year 2002, classified a total of 54.63 million ha as cultivated pastures $(26.8 \%$ of the biome area and $36.8 \%$ of the national pasturelands), mainly in the States of Goias ( 13.0 million ha), Minas Gerais ( 11.8 million ha), and Mato Grosso do Sul ( 11.0 million ha).

The Araguaia basin in the State of Goiás (Figure 1) was selected to gather pasture field data representative of Cerrado, as this basin is the most prominent cattle ranching region in central Brazil and exhibits many of the grass species and conditions found throughout the Cerrado biome [2]. Dominant pasturelands in the Araguaia-Tocantins basin, located in the Cerrado-Amazon transition zone, have caused significant changes in regional runoff, river discharge and atmosphere water transfer from soil reservoirs through vegetation [20-22]. Under the current business-as-usual conversion scenarios, by 2050 this region may undergo a significant reduction in precipitation and up to a one month increase in the dry season length [23,24].

Figure 1. Spatial distribution of cultivated pastures in the Cerrado biome (with selected field sites highlighted). Source: [19].

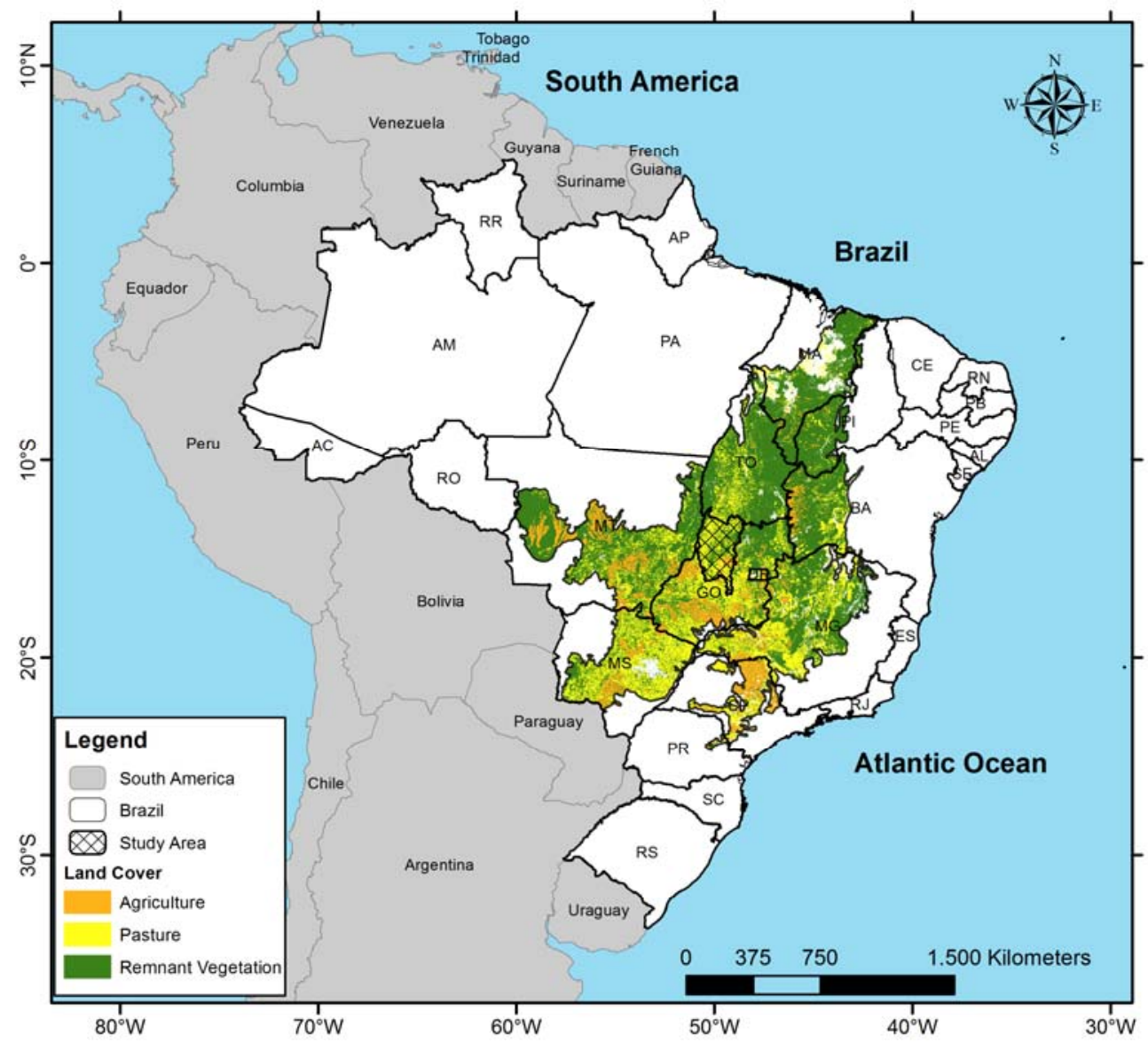




\subsection{Field Data Collection}

Two field campaigns were conducted in the Araguaia basin, from 2 August to 5 August 2009 (dry season) and from 15 February to 18 February 2010 (wet season). Measurements of total above-ground biomass, green above-ground biomass and percent green cover were collected at 27 sampling sites along a 1,000-km path. At each site, three samples of total above-ground biomass were collected by clipping all the green and dry matter within a $0.5 \mathrm{~m} \times 0.5 \mathrm{~m}$ quadrat randomly placed in each sampling site. For every one and two samples, in the dry- and wet-season, respectively, green and dry matters were separated. Estimations of percent green cover were based on nadir-looking digital pictures, taken at a 10-m interval and 1-m height along the south-north direction at each sampling site. The green and total biomass samples were placed in sealed paper bags upon collection and were oven-dried for $96 \mathrm{~h}$ at $65{ }^{\circ} \mathrm{C}$, after which both bags and oven-dried contents were weighted. Biomass estimates, expressed in tons per hectare, were obtained using Equation (1):

$$
B_{t, g}\left(t . h a^{-1}\right)=\frac{B_{w}-b_{w}}{A}=\frac{B_{t, g}\left(g \cdot g^{-1}\right)}{0.25\left(m^{2}\right)} \times \frac{10^{-6}}{4 \times 10^{-4}}
$$

where $B_{t, g}=$ total or green biomass, expressed in tons per hectare; $B_{w}=$ total or green biomass dry weight $(\mathrm{g}) ; b_{w}=$ bag dry weight $(\mathrm{g})$; and $A=$ quadrat area $\left(0.25 \mathrm{~m}^{2}\right)$.

In order to quantitatively determine the \% green cover, each nadir picture was split into its red, green, and blue (RGB) bands and spectrally enhanced, using a green vegetation index (Equation (2)). A "greenness" threshold was then applied, according to which any pixel was considered "green" whenever its green signal was higher than the red value. The proportion of green pixels in each picture was assumed as its respective \% green cover. At the transect level, \% green cover was obtained by averaging the estimations of the 10 pictures taken.

$$
0 \leq \frac{G_{D N}-R_{D N}}{G_{D N}+R_{D N}} \Rightarrow \text { Green }_{\text {pixel }}
$$

where Green $_{\text {pixel }}=$ a pixel identified as green whenever the threshold condition was satisfied; $G_{D N}=$ green band digital number (256 dynamic range); and $R_{D N}=$ red band digital number (256 dynamic range).

\subsection{Orbital Data}

For comparative analysis and field data extrapolation, an orbital imagery dataset, consisting of nine Landsat TM overpasses (six from August 2009 and three from February 2010) and 120 MODIS MOD13Q1 tiles (covering the entire hydrological cycle between July 2009 and July 2010), was obtained through the Brazilian Space Research Institute (INPE) and the NASA Warehouse Inventory Search Tool (WIST), respectively (Figure 2). 
Figure 2. Location of the Landsat scenes (over the 27 field sampling sites) and MODIS tiles (over the entire Cerrado biome).

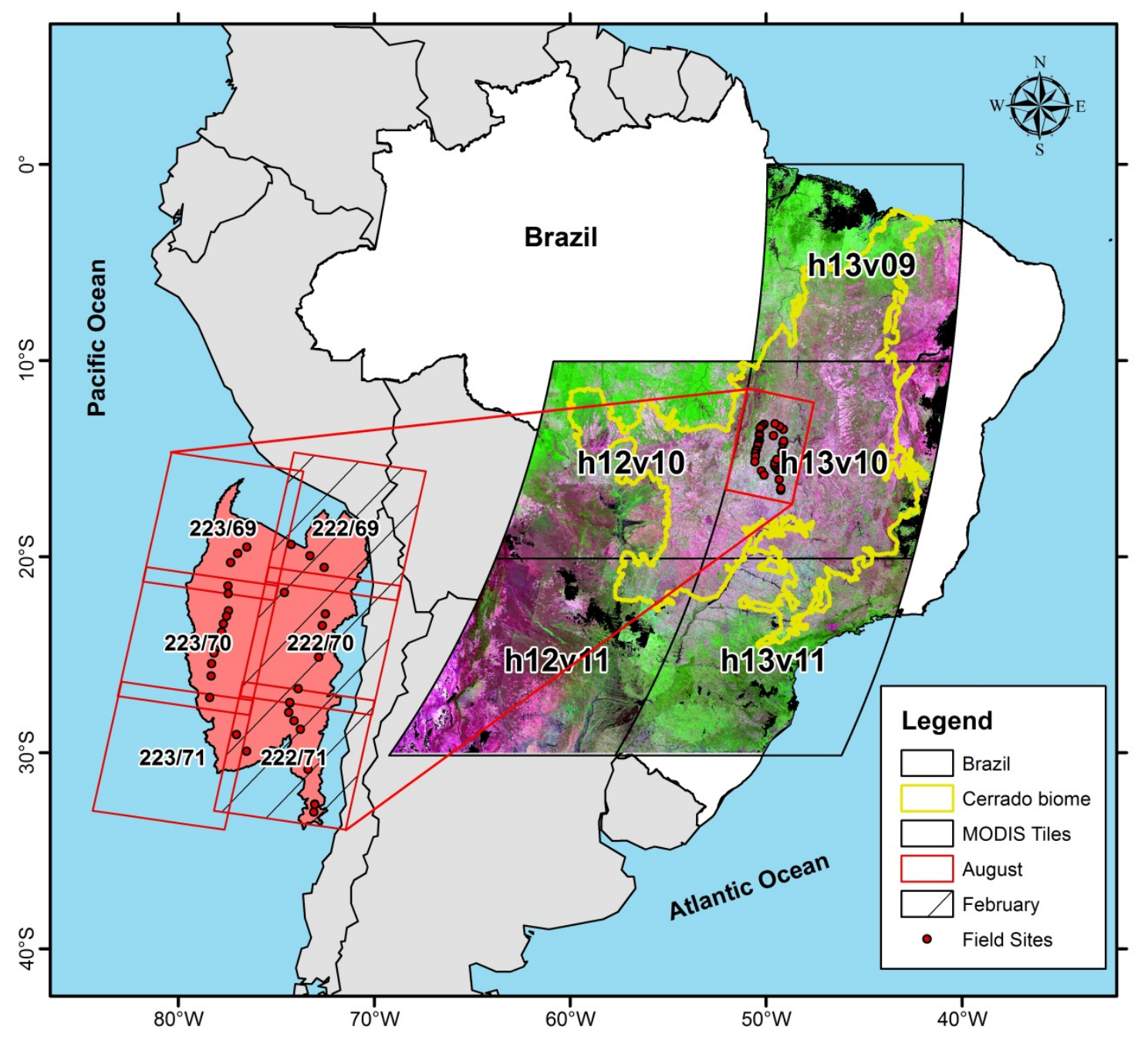

The Landsat images were geometrically rectified (based on the geocover tiles S-22-10_2000 and S-22-15_2000), converted to the "top of atmosphere" apparent reflectances [25,26], and spectrally enhanced via the NDVI (normalized difference vegetation index) and the two-band EVI (enhanced vegetation index) $[27,28]$ :

$$
\begin{gathered}
N D V I=\frac{\rho_{N I R}^{*}-\rho_{\mathrm{Re} d}^{*}}{\rho_{N I R}^{*}+\rho_{\mathrm{Re} d}^{*}} \\
E V I=\frac{\rho_{N I R}^{*}-\rho_{\mathrm{Re} d}^{*}}{\rho_{N I R}^{*}+\rho_{\mathrm{Re} d}^{*}+1} \times 2.5
\end{gathered}
$$

where $\rho^{*}{ }_{\text {NIR }}$ and $\rho_{\text {Red }}$ are the top-of-atmosphere corrected reflectances in the NIR (near infrared) and red bands, respectively.

The MODIS data was screened for aerosols, clouds, and shadows, based on the quality assurance (QA) layer accompanying the validated collection 5 MOD13Q1 product [29], reprojected (from the sinusoidal to the geographical coordinate system), and organized into 24 mosaics (one for every 16-day compositing cycle) over the entire Cerrado region. 


\subsection{Data Analysis}

Following a preliminary and descriptive assessment of the field data's overall biophysical characteristics at each site and for each time period, nine TM pixels were extracted around each site, based on which average NDVI and EVI values were calculated. The Landsat and field data were then regressed so that biophysical images could be derived.

Using a Gaussian convolution filter, weighted according to the MODIS spatial point spread function [30,31], these TM-based images were degraded and resampled to a $250 \mathrm{~m}$ spatial resolution, co-registered, and regressed in relation to the corresponding dry- and wet-season MOD13Q1 Cerrado mosaics (i.e., Day Of the Year-DOY 209 and 33, respectively). Evaluation of the resulting MODIS-based Cerrado biophysical images was conducted comparatively to the amount of renewable fresh water resources (RFWR) available for surface runoff and infiltration [32], considering both the pasture area and respective soil type limits within the 11,190 Brazilian six-order Otto watersheds in the Cerrado (a natural and hierarchical classification system based on the topography and topology of the drainage area) partially or totally covered by cultivated pasturelands. Estimation of RFWR values, for the 2009-2010 hydrological cycle, were based on the difference between the $0.25^{\circ}$ spatial resolution TRMM (Tropical Rainfall Measurement Mission) precipitation data [33] and evapotranspiration obtained from the 1-km MOD16 product [34].

The main steps involved in this study, including the organization, processing, and analysis of distinct datasets, are depicted in Figure 3.

Figure 3. Data and approaches followed in this study for the generation of regional Cerrado pasture biophysical images.

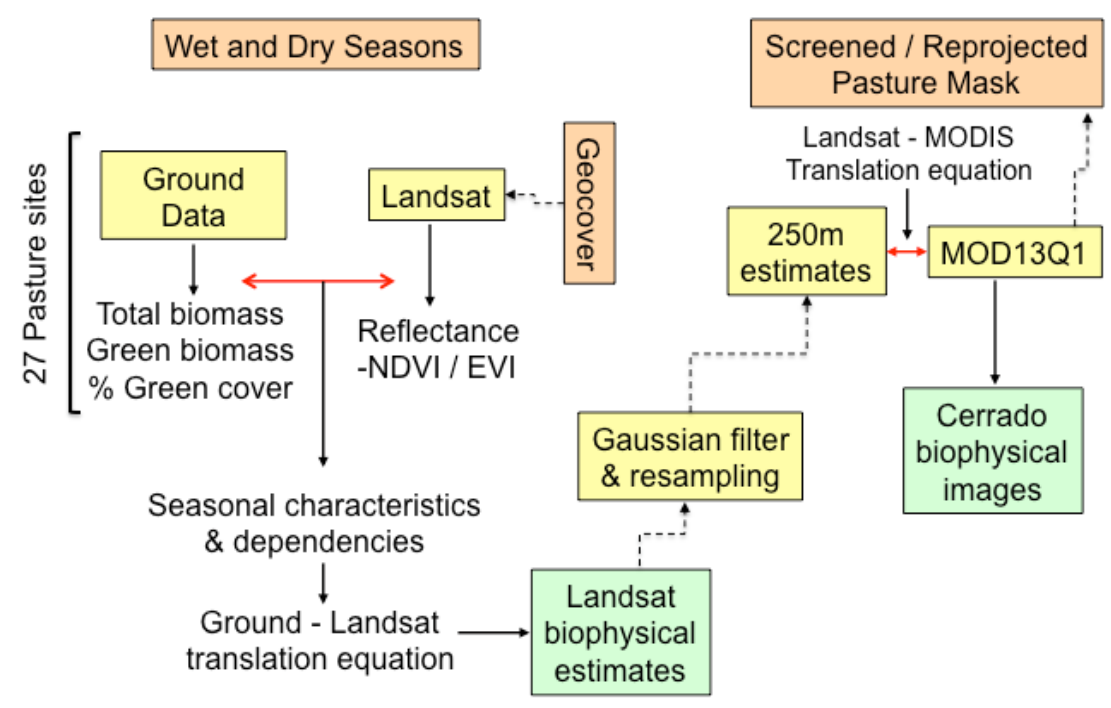

\section{Results}

\subsection{Field Site Data and Correlations}

Dry and wet season biophysical (soil type, \% green cover, total biomass and green biomass), radiometric (NDVI and EVI), and climate (precipitation and RFWR) data for the 27 field sites with Brachiaria spp. (the dominant African grass in the Cerrado biome) are depicted in Table 1. As 
expected, and except for total biomass, with very similar values for both seasons $(\sim 7 \mathrm{t} / \mathrm{ha})$, all other parameters showed strong seasonal variations and more conspicuous spatial variability during the dry season.

Significantly higher wet season values were found for both green biomass $(\sim 3 \mathrm{t} / \mathrm{ha} v s . \sim 1 \mathrm{t} / \mathrm{ha})$ and $\%$ green cover $(66 \%$ vs. $8 \%)(\mathrm{p}<0.05)$. Regarding the spatial variability, while total biomass showed moderate and equivalent coefficient of variation $(\mathrm{CV})$ values in both seasons $(\mathrm{CV}=0.37)$, green biomass and the \% green cover, on the other hand, tended to be highly heterogeneous during the dry season $(\mathrm{CV}=0.59$ and 0.66 , respectively), suggesting that the amount of remaining green leaves (either hidden or on the surface) may be a good indicator of variations due to grazing intensity and productivity. Conversely, during the wet season, both green biomass and \% green cover showed a more uniform distribution ( $\mathrm{CV}=0.35$ and 0.18 , respectively), confirming that most sites recovered from drought stress, though at different rates and intensities.

The substantial and nearly even green up of pastures across sites and respective biomass regrowth (more modest and more asymmetrically distributed) were associated to spatially homogeneous (CVs of 0.08 and 0.07 , respectively) and abundant rainfall (average accumulated precipitation, prior to each field campaign, were about 1,000 mm (January to July 2009) and 2,000 mm (January 2009 to January 2010)). As expected, for all sites, the progressive pasture dry out was preceded and accompanied by pronounced water deficits ( $70 \mathrm{~mm}$, on average), as estimated by the RFWR, i.e., the accumulated difference between precipitation and evapotranspiration from May to July 2009. From August 2009 to January 2010, an average accumulated water surplus (of approximately $700 \mathrm{~mm}$ ) induced overall pasture recovery.

It is interesting to note that none of the 27 sites burned during the time period considered in this study, what can be in part attributed to a relatively low water deficit in the 2009 dry season. Comparatively, in 2010, a strong La Niña year, a much more severe water deficit occurred ( $-108 \mathrm{~mm}$, on average), and about $9,580 \mathrm{~km}^{2}$ of Cerrado's pasture burned ( $\sim 30 \%$ of all burned areas from 2002 to 2010), in spite of only one burning detected in the study area (site \# 9).

Both NDVI and EVI showed similar seasonal responses, with an average increase of about 130\% between August and February. Coefficients of variation were relatively low due to autocorrelation effects in the scaled up data. EVI had slightly higher CV than NDVI, as the enhanced vegetation index is known to be more sensitive to seasonal and spatial variation where green cover is either very high or very low, a situation found in wet- and dry-season pastures here [35].

Correlations between the radiometric and biophysical variables, for both dry- and wet-season values, were weak and statistically non-significant. However, when the two seasons were considered simultaneously, correlations increased substantially, particularly between VIs and \% green cover ( $r=0.95$ and 0.91 , NDVI and EVI, respectively, $\mathrm{p}<0.05)$ and, to a minor extent, between these two VIs and green biomass $(r=0.65$ and 0.62 , NDVI and EVI, respectively, $p<0.05)$ (Table 2). 
Table 1. Dry and wet season biophysical, radiometric and climatic data for the 27 field sites considered in this study. No burning activity was verified during the time period considered in this study. TB = total biomass; GB = green biomass; NDVI = normalized difference vegetation index; EVI = enhanced vegetation index; RFWR = renewable fresh water resources; CV (coefficient of variation); na (not available Landsat data, due to cloud contamination).

\begin{tabular}{|c|c|c|c|c|c|c|c|c|c|c|c|c|c|c|c|}
\hline \multicolumn{9}{|c|}{ Dry Season } & \multicolumn{7}{|c|}{ Wet Season } \\
\hline Site & Soil & $\begin{array}{c}\% \\
\text { Green } \\
\text { Cover }\end{array}$ & $\begin{array}{c}\text { TB } \\
(\mathbf{t} / \mathbf{h a})\end{array}$ & $\begin{array}{c}\text { GB } \\
(\mathbf{t} / \mathbf{h a})\end{array}$ & NDVI & EVI & $\begin{array}{c}\text { Rainfall } \\
\text { Jan-Jul } \\
2009(\mathbf{m m})\end{array}$ & $\begin{array}{c}\text { RFWR } \\
\text { (May-Jul } \\
\text { 2009) }\end{array}$ & $\begin{array}{c}\% \\
\text { Green } \\
\text { Cover }\end{array}$ & $\begin{array}{c}\text { TB } \\
(\mathbf{t} / \mathbf{h a})\end{array}$ & $\begin{array}{c}\text { GB } \\
(\mathbf{t} / \mathbf{h a})\end{array}$ & NDVI & EVI & $\begin{array}{c}\text { Rainfall } \\
\text { (Jan 2009- } \\
\text { Jan 2010 } \\
(\mathrm{mm}) \\
\end{array}$ & $\begin{array}{c}\text { RFWR (Aug } \\
\text { 2009-Jan } \\
\text { 2010) }\end{array}$ \\
\hline & Latossolo & & & & & & & & & & & & & & \\
\hline 1 & $\begin{array}{c}\text { Vermelho-Escuro } \\
\text { (Oxisols) }\end{array}$ & 3.69 & 11.48 & 0.65 & 0.26 & 0.18 & 875.66 & -168.32 & 79.87 & 7.59 & 3.27 & 0.65 & 0.46 & $1,897.46$ & 419.60 \\
\hline 2 & $\begin{array}{l}\text { Argissolos } \\
\text { (Ultisols) }\end{array}$ & 5.49 & 3.45 & 0.42 & 0.20 & 0.12 & $1,004.16$ & -50.54 & 37.25 & 4.35 & 1.52 & 0.51 & 0.34 & $2,039.81$ & 703.25 \\
\hline 3 & $\begin{array}{c}\text { Chernossolos } \\
\text { (Mollisols) }\end{array}$ & 20.63 & 2.64 & 0.56 & 0.31 & 0.22 & $1,021.19$ & -23.51 & 65.91 & 1.63 & 1.08 & 0.59 & 0.43 & $2,099.77$ & 786.17 \\
\hline 4 & $\begin{array}{l}\text { Chernossolos } \\
\text { (Mollisols) }\end{array}$ & 19.46 & 9.01 & 1.94 & 0.27 & 0.16 & $1,021.19$ & 0.29 & 50.58 & 2.72 & 1.76 & 0.58 & 0.38 & $2,099.77$ & 768.27 \\
\hline 5 & $\begin{array}{l}\text { Chernossolos } \\
\text { (Mollisols) }\end{array}$ & 2.86 & 7.71 & 0.04 & 0.19 & 0.10 & $1,031.30$ & 1.53 & 73.27 & 4.00 & 2.70 & 0.55 & 0.35 & $2,066.97$ & 761.47 \\
\hline 6 & $\begin{array}{c}\text { Chernossolos } \\
\text { (Mollisols) }\end{array}$ & 7.89 & 9.00 & 0.61 & 0.23 & 0.16 & $1,031.30$ & -92.37 & 79.50 & 8.24 & 4.50 & 0.68 & 0.50 & $2,066.97$ & 566.07 \\
\hline 7 & $\begin{array}{c}\text { Chernossolos } \\
\text { (Mollisols) }\end{array}$ & 12.61 & 4.67 & 0.95 & 0.21 & 0.15 & $1,031.30$ & 12.33 & 58.03 & 4.62 & 2.01 & 0.67 & 0.51 & $2,066.97$ & 742.37 \\
\hline 8 & $\begin{array}{c}\text { Chernossolos } \\
\text { (Mollisols) }\end{array}$ & 10.15 & 5.39 & 1.11 & 0.26 & 0.17 & 924.45 & -122.69 & 75.76 & 7.69 & 3.22 & 0.61 & 0.43 & $1,986.38$ & 608.73 \\
\hline 9 & $\begin{array}{c}\text { Chernossolos } \\
\text { (Mollisols) }\end{array}$ & 8.94 & 7.14 & 1.68 & 0.25 & 0.17 & 817.77 & -137.73 & 57.38 & 4.26 & 3.29 & 0.54 & 0.34 & $1,690.96$ & 443.39 \\
\hline 10 & $\begin{array}{l}\text { Argissolos } \\
\text { (Ultisols) }\end{array}$ & 5.12 & 4.05 & 0.62 & 0.28 & 0.16 & 776.27 & -161.96 & 63.12 & 7.43 & 3.22 & 0.51 & 0.27 & $1,744.32$ & 558.65 \\
\hline 11 & $\begin{array}{l}\text { Argissolos } \\
\text { (Ultisols) }\end{array}$ & 2.28 & 9.81 & 3.11 & 0.28 & 0.15 & 989.13 & -80.81 & 71.54 & 6.04 & 3.09 & 0.51 & 0.35 & $2,103.78$ & 711.05 \\
\hline
\end{tabular}


Table 1. Cont.

\begin{tabular}{|c|c|c|c|c|c|c|c|c|c|c|c|c|c|c|c|}
\hline \multirow[b]{2}{*}{ Site } & \multicolumn{7}{|c|}{ Dry Season } & \multirow[b]{2}{*}{$\begin{array}{c}\text { RFWR } \\
\text { (May-Jul } \\
\text { 2009) }\end{array}$} & \multicolumn{7}{|c|}{ Wet Season } \\
\hline & Soil & $\begin{array}{c}\% \\
\text { Green } \\
\text { Cover }\end{array}$ & $\begin{array}{c}\text { TB } \\
\text { (t/ha) }\end{array}$ & $\begin{array}{c}\text { GB } \\
(\mathbf{t} / \mathbf{h a})\end{array}$ & NDVI & EVI & $\begin{array}{c}\text { Rainfall } \\
\text { Jan-Jul } \\
2009(\mathbf{m m})\end{array}$ & & $\begin{array}{c}\% \text { Green } \\
\text { Cover }\end{array}$ & $\begin{array}{c}\text { TB } \\
\text { (t/ha) }\end{array}$ & $\begin{array}{c}\text { GB } \\
(\mathbf{t} / \mathbf{h a})\end{array}$ & NDVI & EVI & $\begin{array}{c}\text { Rainfall } \\
\text { (Jan 2009- } \\
\text { Jan 2010 } \\
\text { (mm) }\end{array}$ & $\begin{array}{c}\text { RFWR (Aug } \\
\text { 2009-Jan } \\
\text { 2010) }\end{array}$ \\
\hline 12 & $\begin{array}{l}\text { Podzólico } \\
\text { Vermelho- } \\
\text { Amarelo }\end{array}$ & 3.34 & 5.59 & 1.17 & 0.26 & 0.14 & 964.13 & 0.19 & 77.11 & 10.01 & 4.52 & 0.62 & 0.43 & $1,919.35$ & 636.92 \\
\hline 13 & $\begin{array}{c}\text { Argissolos } \\
\text { (Ultisols) }\end{array}$ & 8.24 & 7.40 & 2.05 & 0.28 & 0.18 & 899.89 & -111.45 & 65.79 & 4.73 & 2.10 & 0.49 & 0.31 & $1,885.96$ & 600.17 \\
\hline 14 & $\begin{array}{c}\text { Latossolo } \\
\text { Vermelho- } \\
\text { Amarelo (Oxisols) }\end{array}$ & 15.28 & 7.29 & 2.39 & 0.24 & 0.17 & $1,023.95$ & -32.00 & 54.30 & 10.60 & 3.38 & na & na & $2,206.81$ & 901.36 \\
\hline 15 & $\begin{array}{c}\text { Latossolo } \\
\text { Vermelho- } \\
\text { Amarelo (Oxisols) }\end{array}$ & 3.85 & 4.58 & 1.46 & 0.22 & 0.17 & $1,069.18$ & -42.35 & 64.05 & 8.23 & 2.46 & na & na & $2,296.38$ & 930.90 \\
\hline 16 & $\begin{array}{c}\text { Latossolo } \\
\text { Vermelho- } \\
\text { Amarelo (Oxisols) }\end{array}$ & 2.67 & 10.33 & 0.70 & 0.22 & 0.14 & 958.35 & -30.61 & 61.96 & 4.87 & 2.60 & na & na & $2,102.94$ & 831.39 \\
\hline 17 & $\begin{array}{c}\text { Latossolo } \\
\text { Vermelho- } \\
\text { Amarelo (Oxisols) }\end{array}$ & 6.35 & 8.47 & 1.96 & 0.21 & 0.14 & 958.35 & -46.81 & 53.56 & 9.96 & 4.31 & na & na & $2,102.94$ & 821.79 \\
\hline 18 & $\begin{array}{c}\text { Latossolo } \\
\text { Vermelho- } \\
\text { Amarelo (Oxisols) }\end{array}$ & 11.53 & 9.83 & 2.21 & 0.26 & 0.18 & 994.32 & -33.64 & 61.01 & 5.19 & 2.93 & na & na & $2,052.90$ & 758.38 \\
\hline 19 & $\begin{array}{c}\text { Latossolo } \\
\text { Vermelho- } \\
\text { Amarelo (Oxisols) }\end{array}$ & 4.85 & 8.12 & 2.44 & 0.26 & 0.19 & 994.32 & -163.24 & 65.12 & 7.60 & 3.01 & na & na & $2,052.90$ & 550.88 \\
\hline
\end{tabular}


Table 1. Cont

\begin{tabular}{|c|c|c|c|c|c|c|c|c|c|c|c|c|c|c|c|}
\hline \multicolumn{9}{|c|}{ Dry Season } & \multicolumn{7}{|c|}{ Wet Season } \\
\hline Site & Soil & $\begin{array}{c}\% \\
\text { Green } \\
\text { Cover }\end{array}$ & $\begin{array}{c}\text { TB } \\
(\mathbf{t} / \mathbf{h a})\end{array}$ & $\begin{array}{c}\text { GB } \\
(\mathbf{t} / \mathbf{h a})\end{array}$ & NDVI & EVI & $\begin{array}{c}\text { Rainfall } \\
\text { Jan-Jul } \\
2009(\mathbf{m m})\end{array}$ & $\begin{array}{c}\text { RFWR } \\
\text { (May-Jul } \\
\text { 2009) }\end{array}$ & $\begin{array}{c}\% \\
\text { Green } \\
\text { Cover }\end{array}$ & $\begin{array}{c}\text { TB } \\
(\mathbf{t} / \mathbf{h a})\end{array}$ & $\begin{array}{c}\text { GB } \\
(\mathbf{t} / \mathbf{h a})\end{array}$ & NDVI & EVI & $\begin{array}{c}\text { Rainfall } \\
\text { (Jan 2009- } \\
\text { Jan 2010 } \\
\text { (mm) }\end{array}$ & $\begin{array}{c}\text { RFWR } \\
\text { (Aug 2009- } \\
\text { Jan 2010) }\end{array}$ \\
\hline 20 & $\begin{array}{c}\text { Latossolo } \\
\text { Vermelho-Amarelo } \\
\text { (Oxisols) }\end{array}$ & 8.12 & 9.76 & 1.87 & 0.25 & 0.18 & 993.98 & -60.78 & 51.69 & 8.33 & 4.43 & na & na & $2,073.98$ & 756.40 \\
\hline 21 & $\begin{array}{c}\text { Latossolo } \\
\text { Vermelho-Amarelo } \\
\text { (Oxisols) }\end{array}$ & 17.35 & 7.95 & 2.15 & 0.25 & 0.17 & $1,085.30$ & -59.43 & 71.76 & 6.29 & 2.82 & na & na & $2,109.93$ & 733.93 \\
\hline 22 & $\begin{array}{c}\text { Latossolo } \\
\text { Vermelho-Amarelo } \\
\text { (Oxisols) }\end{array}$ & 5.71 & 6.17 & 1.24 & 0.23 & 0.17 & $1,085.30$ & -156.33 & 55.60 & 10.86 & 3.05 & na & na & $2,078.35$ & 598.73 \\
\hline 23 & $\begin{array}{c}\text { Latossolo } \\
\text { Vermelho-Amarelo } \\
\text { (Oxisols) }\end{array}$ & 4.67 & 9.36 & 0.96 & 0.28 & 0.20 & $1,051.61$ & -137.03 & 66.49 & 8.44 & 3.04 & na & na & $2,239.45$ & 413.84 \\
\hline 24 & $\begin{array}{c}\text { Latossolo } \\
\text { Vermelho-Amarelo } \\
\text { (Oxisols) }\end{array}$ & 4.84 & 6.73 & 1.50 & 0.23 & 0.16 & $1,036.68$ & -2.35 & 87.72 & 7.30 & 4.70 & na & na & $2,248.44$ & 953.46 \\
\hline 25 & $\begin{array}{l}\text { Cambissolos } \\
\text { (Inceptisols) }\end{array}$ & 3.34 & 6.38 & 2.03 & 0.25 & 0.18 & $1,037.84$ & -24.64 & 67.81 & 9.83 & 5.65 & na & na & $2,271.09$ & 906.21 \\
\hline 26 & $\begin{array}{l}\text { Cambissolos } \\
\text { (Inceptisols) }\end{array}$ & 7.89 & 2.40 & 0.31 & 0.23 & 0.16 & $1,105.92$ & -25.56 & 69.40 & 5.82 & 3.37 & na & na & $2,271.09$ & 844.57 \\
\hline 27 & $\begin{array}{l}\text { Cambissolos } \\
\text { (Inceptisols) }\end{array}$ & 18.77 & 2.30 & 0.41 & 0.31 & 0.18 & $1,009.31$ & -156.59 & 91.07 & 9.55 & 5.69 & 0.56 & 0.36 & $2,131.64$ & 634.23 \\
\hline Average & & 8.37 & 6.93 & 1.35 & 0.25 & 0.16 & 992.30 & -70.61 & 65.80 & 6.90 & 3.25 & 0.58 & 0.39 & $2,070.64$ & 701.56 \\
\hline $\mathrm{CV}$ & & 0.66 & 0.37 & 0.59 & 0.12 & 0.14 & 0.08 & 0.85 & 0.18 & 0.36 & 0.35 & 0.11 & 0.18 & 0.07 & 0.22 \\
\hline
\end{tabular}


Table 2. Correlation matrix regarding the key biophysical variables evaluated in this study, simultaneously considering data from both dry- and wet-season.

\begin{tabular}{cccccc}
\hline \multicolumn{5}{c}{ Wet and Dry Seasons Combined } \\
\hline & Total Biomass (t/ha) & Green Biomass (t/ha) & \% Green Cover & NDVI & EVI \\
\hline Total Biomass ( $\mathrm{t} / \mathrm{ha})$ & 1.00 & & & & \\
Green Biomass ( $\mathrm{t} / \mathrm{ha})$ & 0.36 & 1.00 & & & \\
\% Green Cover & -0.11 & 0.72 & 1.00 & & \\
NDVI & -0.16 & 0.65 & 0.95 & 1.00 & \\
EVI & -0.14 & 0.62 & 0.91 & 0.98 & 1.00 \\
\hline
\end{tabular}

\subsection{Regression Analysis}

Based on the above relationships, combined wet- and dry-season $\%$ green cover and green biomass field estimates were regressed against TM NDVI values (Figure 4). Although the significant correlation $\left(r^{2}=0.46\right)$, satellite NDVI clearly saturated in relation to green biomass (Figure 4(A)), which can be in part attributed to the limitation of optical VI's in retrieving volumetric parameters such as biomass. On the other hand, the much more precise and accurate NDVI-\% green cover regression equation $\left(\%\right.$ green cover $\left.=181.17 \times \mathrm{NDVI}-36.09 ; \mathrm{r}^{2}=0.92\right)($ Figure 4(B) $)$ was applied to all nine Landsat-based NDVI images, so that $30-\mathrm{m} \%$ green cover values were generated over a much larger area and a wider variety of pasture types and conditions (Figure 5).

Figure 4. Regressed ground estimates of green biomass (A) and \% green cover (B) relatively to Landsat TM NDVI values.
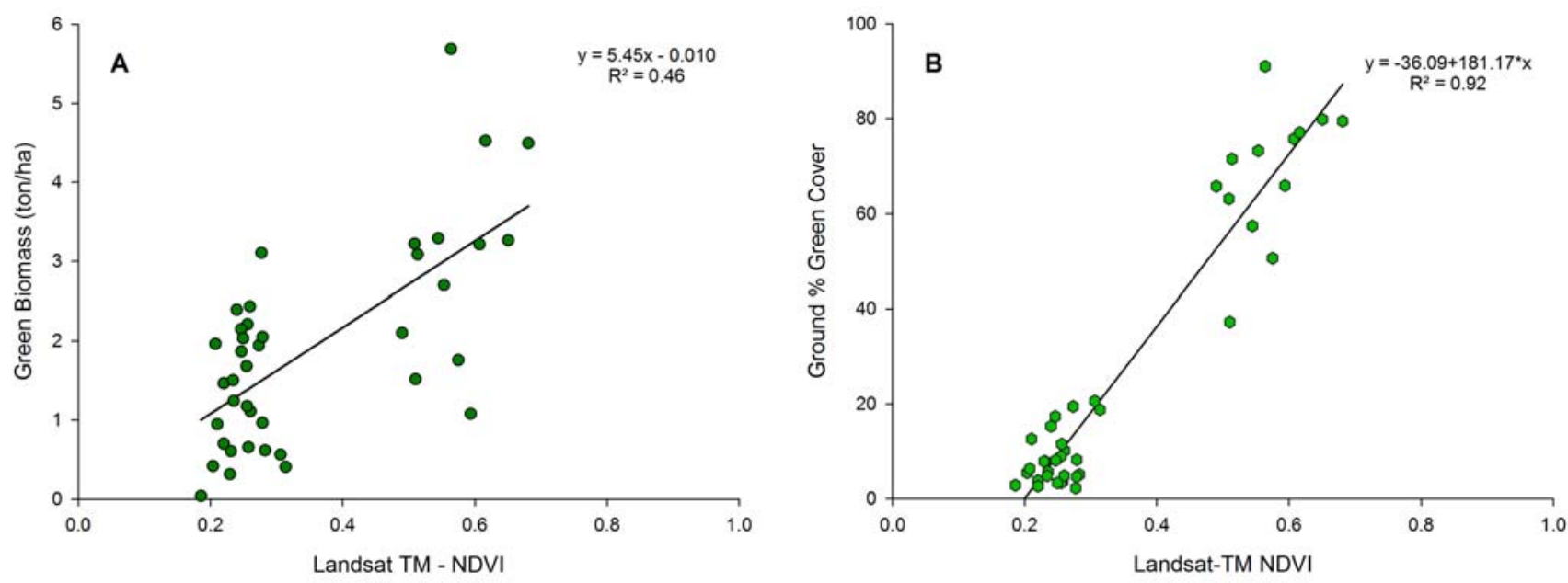

In sequence, the regression between the nine NDVI TM-based \% green cover images (degraded and resampled to a 250-m spatial resolution) and the wet- and dry-season MOD13Q1 NDVI composites (Day Of the Year-DOY 33 and 209, respectively) resulted in a new translation equation (Figure 5), which, in spite of being based on only two time points (August 2009 and February 2010), was able to capture most of the seasonal biophysical and radiometric variations occurring along the whole annual hydrological cycle. As seen in Figure 6, based on average MODIS values (obtained at 50 random pasture locations throughout the Cerrado biome), the interval between the MODIS composites 209 
(August 2009) and 33 (February 2010) encompassed about $80 \%$ of the expected radiometric variation, which corresponded to a relative variation of about $127 \%$ in the pasture $\%$ green cover.

Figure 5. \% Green cover values based on the MODIS NDVI regressed against the TM-derived biophysical images.

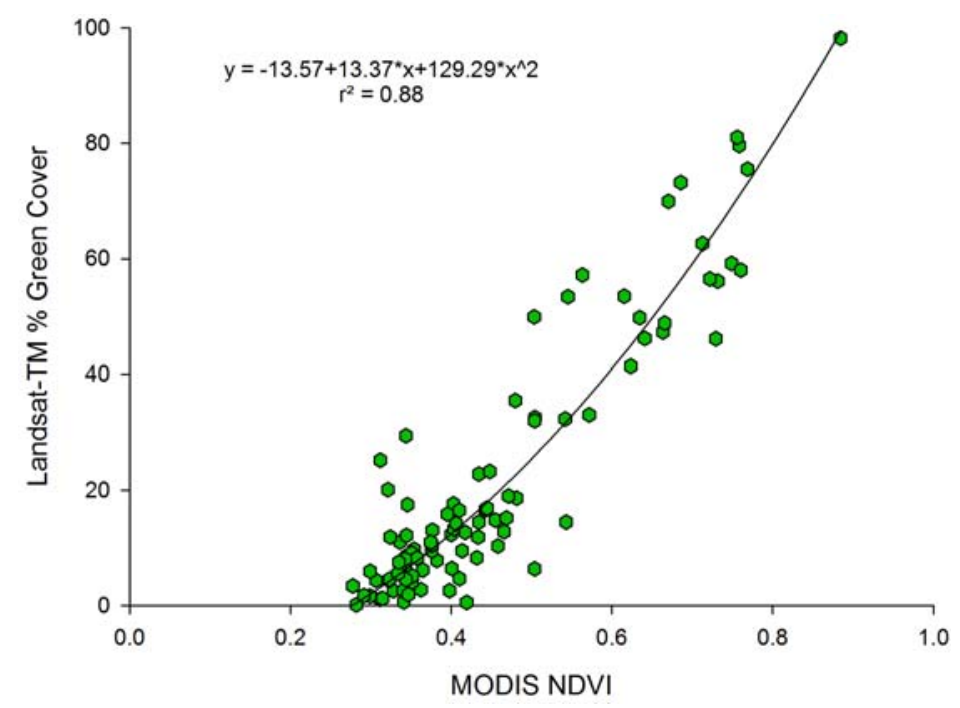

Figure 6. MODIS NDVI seasonal variation (August 2009-August 2010) and distribution of MODIS based \% green cover along the 2009-2010 hydrological cycle.

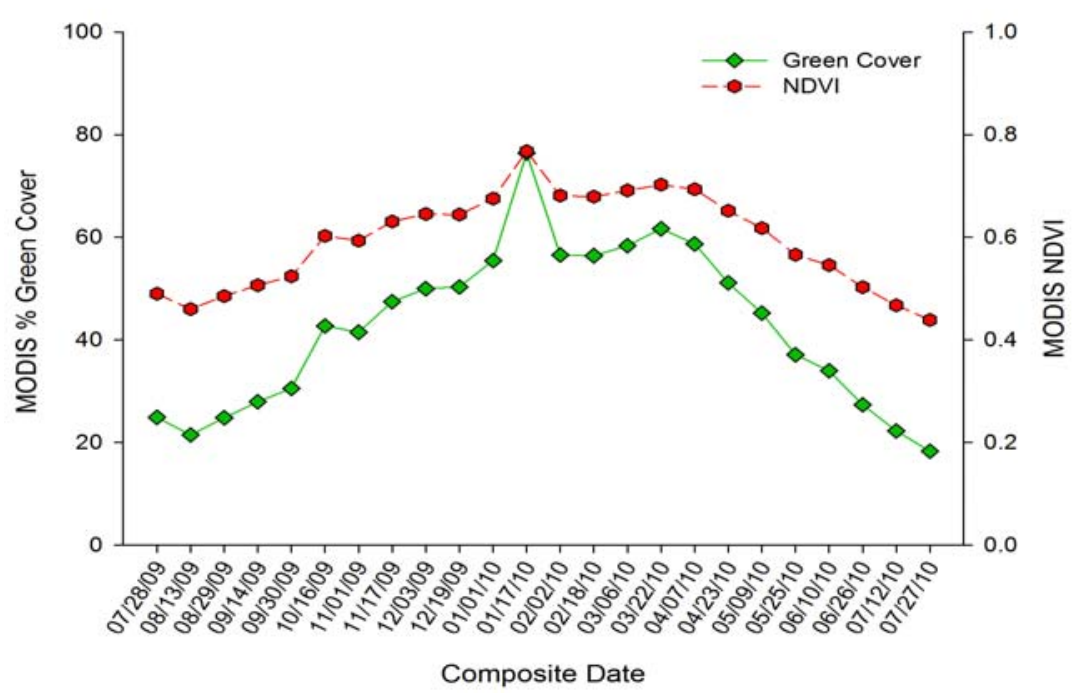

\subsection{Greenness Spatial Patterns and Hydrological Drivers}

Regional greenness estimates, for the period between July 2009 and July 2010 (16-day interval), obtained from the transformation of the 24 MODIS NDVI composites through the use of the MODIS-Landsat regression, are shown in Figure 7. Despite the large latitudinal variation, Cerrado cultivated pastures remain mostly green from October through May, with an overall peak around January (75\%) (Figure 6), although increasing greenness values were mostly found in the southern portions of the biome, due to local conditions (e.g., more fertile soils) and management practices. Interannual variability was also evident in the time series (Figure 7), with coincident periods being 
greener in 2009 (e.g., 28 July, 27\%), comparatively to 2010 (e.g., 27 July, 20\%), a year marked by a strong La Niña event, which started in March and caused a prolonged and more intensive dry season than usual [36].

Figure 7. MODIS-based \% green cover images for the 2009-2010 hydrological cycle.
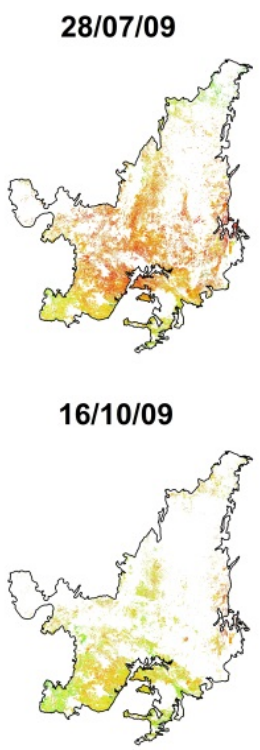

01/01/10

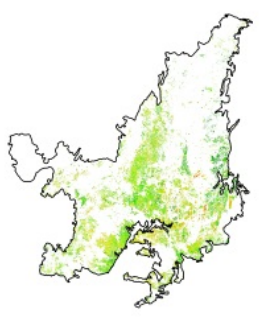

22/03/10

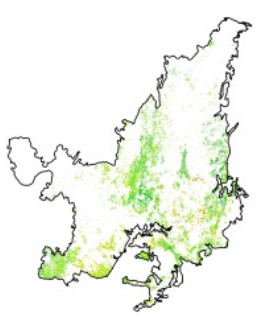

$10 / 06 / 10$

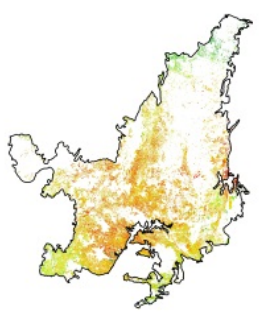

$13 / 08 / 09$

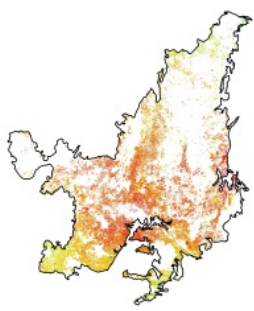

$01 / 11 / 09$

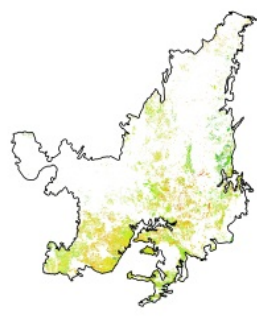

$17 / 01 / 10$

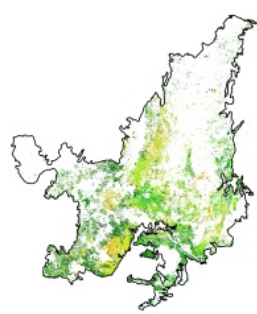

07/04/10

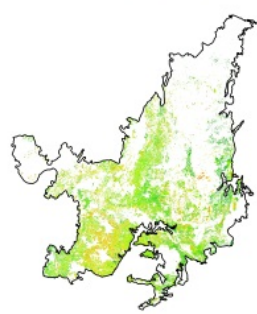

26/06/10

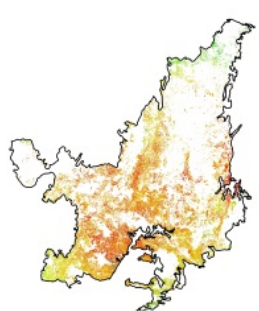

29/08/09

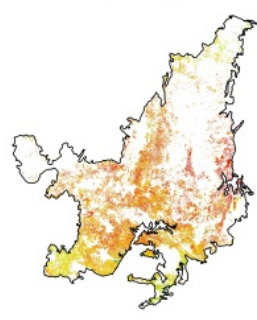

17/11/09

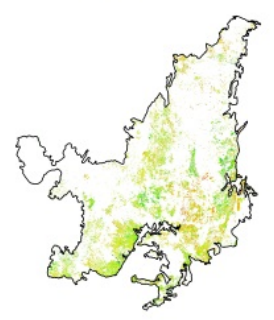

$02 / 02 / 10$

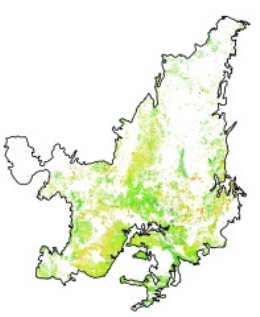

$23 / 04 / 10$

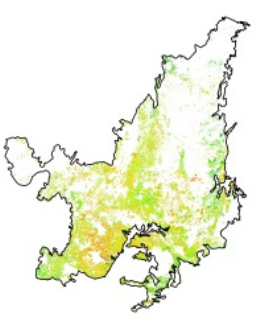

$12 / 07 / 10$

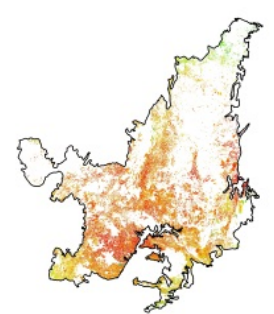

14/09/09

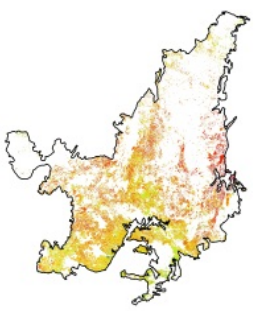

03/12/09

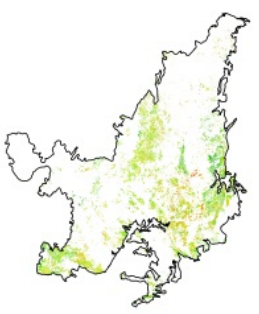

$18 / 02 / 10$

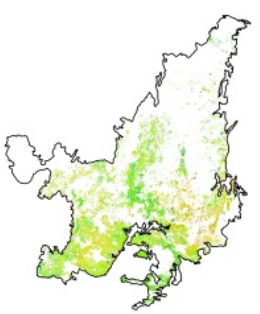

09/05/10

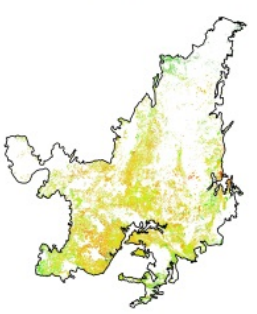

27/07/10

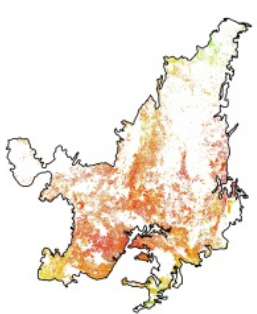

30/09/09

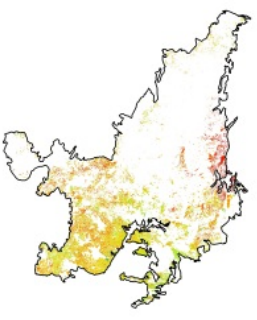

09/12/09

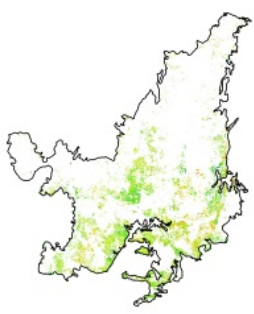

06/03/10

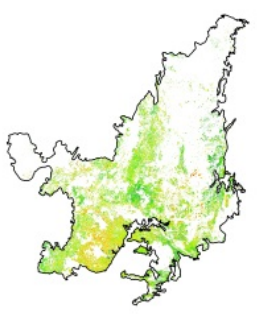

25/05/10

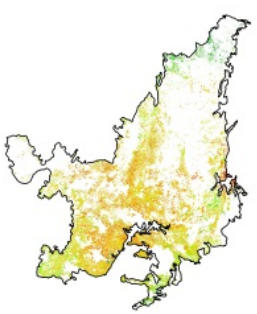

MODIS \%Green

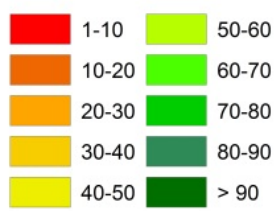

Overall patterns and differences in pasture biophysical responses are shown in Figure 8, in which annual mean pasture greenness values (along the entire 2009-2010 hydrological cycle), according to watershed and soil limits, are compared to the accumulated dry- and wet-season available water in 
plant root zones and groundwater storage (RFWR). While very low \% green cover values tended to be more prevalent in the northern (particularly Maranhao, Piaui, and Tocantins) and northwestern (Mato Grosso) states, average greenness was dominant in Goiás, Minas Gerais, and Mato Grosso do Sul, all of which are important cattle ranching States, and significantly above average values were found in the most southern Cerrado State of São Paulo, which is also the most prominent consumption center in the entire country, with well-established and competitive agriculture practices.

Figure 8. Annual mean greenness values (2009-2010 hydrological cycle) (A), relation between dry- and wet-season RFWR and annual mean \% green cover (B), and accumulated available water for wet (C) and dry (D) seasons (pasture greenness and RFWR values distributed according to soil and watershed limits).
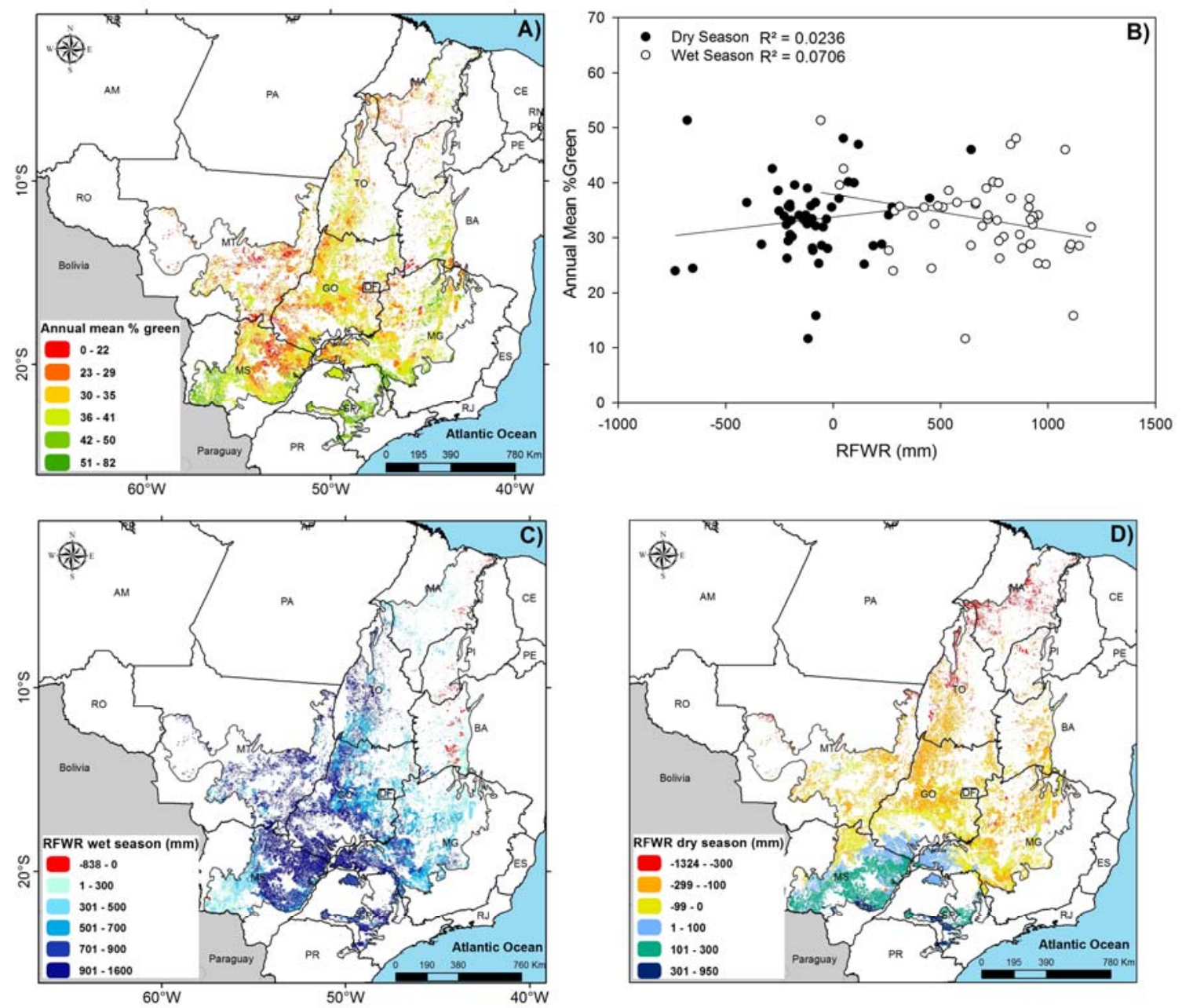

The relationship between 50 randomly selected RFWR values and their corresponding annual mean $\%$ green cover was slightly positive for dry season and slightly negative for wet season, evoking opposing trends (Figure 8(B)). While the rather narrow range of dry season RFWR values suggests that moderate water deficit is widespread across the Cerrado pastures during the May-July period, pasture response to the drought stress varies significantly, indicating that the ability to endure drought is more important than the available water accumulated in the subsequent months (August to January). Certainly, water deficit is not the only factor controlling the amount of pasture's green cover (as indicated by the low and non-significant correlations). Pasture degradation, common in the Cerrado 
and related to loss of biomass productivity, can influence the strength of the green-up at the onset of the rainy season, e.g., [37,38]. Mixed responses and uncertainties can also arise from the fact that poorly managed pastures can present high occurrence of invasive species or regrowth of native tree and shrub species, increasing the \% green cover.

In general, Cerrado pastures with high greenness values are either related with high natural soil fertility (such as soils derived from basalts in the southeastern part of Goiás State) or to regions less affected by the water deficiency (e.g., Sao Paulo). On the other hand, pastures located in the northern part of the Cerrado tended to present low annual mean \% green cover due to high water deficits and low natural soil fertility (e.g., highly leached sandy soils). Pastures in the western part of the Cerrado also presented relatively low annual mean \% green cover. As shown in Figure $8(\mathrm{C})$, this is the region facing the highest water deficits in the wet season. The observed average distribution of annual mean pasture greenness values relatively to the major soil classes in the Cerrado, i.e., Oxisols, Ultisols, and Inceptisols (around 46\%, 15\%, and 10\% of the total Cerrado area, respectively), somewhat corroborates a positive correlation between pasture condition and soil chemical and water capacity, in which the most fertile Ultisols were associated with slightly higher greenness values, followed by Oxisols and the weakly developed Inceptisols (Figure 9).

Figure 9. Average distribution of annual mean greenness values (2009-2010 hydrological cycle) according to the major Cerrado soil classes.

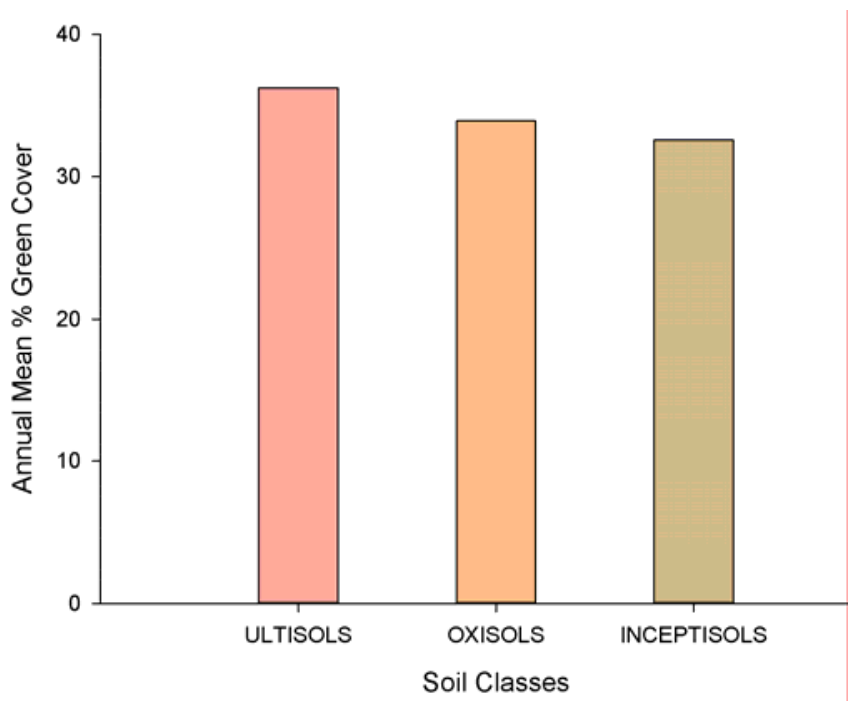

\section{Discussion}

Due to the apparent simplicity of their structure and physiology, grasslands have been the subject of many remote sensing studies aimed at understanding vegetation reflectance properties and their significance to plant and ecosystem processes [39,40]. Whereas ground-level measurements give a limited assessment of spatial and temporal variability, remotely sensed observations can assist extrapolations to larger scales.

Broad-scale assessments of the state and structure of managed grassland systems generally require the identification of several variables (e.g., vertical structure, percentage cover, greenness, and distribution of soil and litter). However, because of the complex physiological responses of disturbed systems to resource availability and other potentially limiting factors [41], single factor measurements, 
such as the photosynthetic capacity, through the estimation of the fraction of absorbed photosynthetically active radiation (fAPAR), often associated with NDVI, may be insufficient to adequately characterize the ecosystem state and conditions [42].

Thus, other remote sensing derived parameters, as the ones shown in this study, can provide important insight into the pasture overall characteristics and conditions, through the identification of where grazing intensity has exceeded management inputs for sufficiently long periods to induce significant increases in coverage of senescent foliage and exposed soil [18]. Our results indicate that simple metrics, based on the combined use of moderate and high spatial resolution images, can depict major spatial and temporal biophysical variations at the landscape scale. Nevertheless, consistent biophysical retrieval and monitoring of pasture dynamics needs to take into account the effects of scaling, which varies according to the degree of spatial averaging involved and also depends on the nature, distribution patterns, and size of neighboring end-member targets [43]. The accuracy and precision of ground to image extrapolation is also proportional to the amount, area distribution and frequency of the samples, based on which, the utilized translation equations were defined and constrained [44].

Likewise, the interpretation of image-based metrics needs to consider management practices, which may influence the ability of remote sensing techniques to accurately detect degradation, as nutrient cycling, ecosystem composition, and distribution of organic matter are regulated in ways that deviate from undisturbed systems [41,45]. Furthermore, conspicuous seasonal variability, common in most grasslands, can lead to frequent alterations in ecosystem resource dynamics, further exacerbated due to management practices over time. This transient nature of resource availability results in a complexity of ecosystem structure and functioning that can confound estimates of grassland system properties and conditions [46].

\section{Conclusions}

As pasture has become the dominant land use type in the Cerrado, the low impact cattle ranching on relatively natural, unaltered pasture lands, typically seen before the 1970's, has changed to the more intensive forms of grazing observed today, and conversion for new pasture continues to be the main driver behind land clearings. Much of this intensification has occurred due to the rapid expansion of demand in the domestic and export beef markets. Intensive pasture has also to compete with other expanding land uses in the Cerrado, such as the industrial-scale agriculture for commodity export crops and biofuels.

Recently, the issue of pasture quality and degradation has been linked to the biofuel production by new government policies that constrain future large sugarcane production zones almost exclusively in areas of "degraded pasture" [47]. These policies were developed as a response to widespread concerns that large-scale expansion of sugarcane production for ethanol would result in significant increases in natural area loss in the Cerrado [48,49]. However, what the term "degraded pasture" actually represents ecologically has not been well-defined yet, and is currently a subject of varying interpretation. This uncertainty has resulted in a wide range of estimates of areas appropriate for sugarcane expansion that would also reduce or eliminate deforestation. 
This study, focused on large-scale patterns observed from satellite data, was the first and most comprehensive attempt to analyze, at both the temporal and spatial domains, the pasture areas in central Brazil, regarding their biophysical characteristics and responses to physical constraints and management practices. Although critical issues related to sampling representativeness and ground-to-satellite coupling need to be further investigated, our results clearly demonstrated the ability of empirical-based scaling approaches to extrapolate pasture ground observations. These results, within the exploratory and preliminary scope or our study, certainly provide meaningful insights on the pulse, conditions, and distribution patterns of the Cerrado pastures, which are, to some degree, dependent on the regional hydrologic behavior and soil attributes.

Undoubtedly, pasture quality assessments based on satellite remote sensing are instrumental for developing new methods for defining and quantifying "degradation", especially in grassland regions which are prospectively targeted for widespread and rapid conversion to agriculture and livestock production. The development of enhanced biophysically-based landscape degradation indices could significantly improve efforts to promote more protective land use strategies and increase natural area conservation, such as in the threatened Cerrado.

\section{Acknowledgments}

This study was conducted with support from the Brazilian Research Council (CNPq/grant \#471198/2009-9), the Brazilian Financing Agency for Studies and Projects (FINEP/CT-Hidro), the NASA Land-Cover/Land-Use Change Program (grant \#NNX11AE56G), and the Stanford University Global Climate and Energy Project (GCEP). First, third, fourth and last authors also acknowledge $\mathrm{CNPq}$ for individual research grants.

\section{References}

1. CNPC. Balanço de Pecuária Bovídea de Corte: 1994-2010; CNPC: São Paulo, Brazil, 2011.

2. Bustamante, M.M.C.; Nobre, C.A.; Smeraldi R.; Aguiar, A.P.D.; Barioni, L.G.; Ferreira, L.G.; Longo, K.; May, P.; Ometto, J.P.H.; Pinto, A.S. Estimating greenhouse gas emissions from cattle raising in Brazil. Climatic Change 2012, doi: 10.1007/s10584-012-0443-3.

3. Sano, E.E.; Barcellos, A.O.; Bezerra, H.S. Assessing the spatial distribution of cultivated pastures in the Brazilian savanna. Pasturas Tropicales 2000, 22, 2-15.

4. Brossard, M.; Barcellos, O. Conversão do cerrado em pastagens cultivadas e funcionamento de latossolos. Cadernos de Ciências \& Tecnologia 2005, 22, 153-168.

5. Myers, N.; Mittermeier, R.A.; Mittermeier, C.G., Fonseca, G.A.B.; Kent, J. Biodiversity hotspots for conservation priorities. Nature 2000, 403, 853-858.

6. Jepson, W. A disappearing biome? Reconsidering land cover change in the Brazilian savanna. Geogr. J. 2005, 17, 99-111.

7. Klink, C.A.; Machado, R.B. A conservação do Cerrado brasileiro. Megadiversidade 2005, 1, 147-155.

8. Sano, E.E.; Rosa, R.; Brito, J.L.S.; Ferreira, L.G. Land cover mapping of the tropical savanna region in Brazil. Environ. Monit. Assess. 2010, 166, 113-124. 
9. Carvalho, F.M.V.; de Marco, P.; Ferreira. L.G., Jr. The Cerrado into pieces: Habitat fragmentation as a function of landscape use in the savannas of central Brazil. Biol. Conserv. 2009, 142, 1392-1403.

10. Bustamante, M.; Ferreira, L.G. Land Use Change and the Carbon Budget in the Brazilian Cerrado. In Ecosystem Function in Savannas: Measurement and Modeling at Landscape to Global Scales; Hill, M.J., Niall, P., Hanan, N.P., Eds.; CRC Press: Boca Raton, FL, USA, 2010; pp. 367-382.

11. Martha, G.B.; Vilela, L. Pastagens no Cerrado: Baixa Produtividade pelo Uso Limitado de Fertilizantes; Embrapa Cerrados: Planaltina, Brazil, 2002.

12. Oliveira, O.C.; Oliveira, I.P.; Alves, B.J.R.; Urquiaga, S.; Boddey, R.M. Chemical and biological indicators of decline/degradation of Brachiaria pasture in the Brazilian Cerrado. Agri. Ecosyst. Environ. 2004, 103, 289-300.

13. Macedo, M.C.M. Pastagens No Ecossistema Cerrados. In SIMPÓSIO SOBRE PASTAGENS NOS ECOSSISTEMAS BRASILEIROS: Pesquisas Para O Desenvolvimento Sustentável; Sociedade Brasileira de Zootecnia: Brasília, Brazil, 1995; pp. 28-62.

14. Garcia-Oliva, F.; Lancho, J.F.G.; Montano, N.M.; Islas, P. Soil carbon and nitrogen dynamics followed by a forest-to-pasture conversion in western Mexico. Agroforest. Syst. 2006, 66, 93-100.

15. Rocha, G.F.; Ferreira, L.G.; Ferreira, N.C.; Ferreira, M.E. Detecção de desmatamentos no bioma Cerrado entre 2002 e 2009: Padrões, tendências e impactos. Rev. Bras. Cartografia 2011, 63, 341-349.

16. Ferreira, M.E.; Silva, J.R.; Rocha, G.F.; Antoniazzi, L.; Nassar, A. Caracterização das áreas desmatadas no bioma Cerrado via sensoriamento remoto: uma análise sobre a expansão de culturas agrícolas e pastagens cultivadas. In Proceedings of Simpósio Brasileiro de Sensoriamento Remoto, Curitiba, Brazil, 30 April 2011; pp. 6727-6733.

17. Numata, I.; Roberts, D.A.; Chadwick, O.A.; Schimel, J.; Sampaio, F.R.; Leonidas, F.C.; Soares, J.V. Characterization of pasture biophysical properties and the impact of grazing intensity using remotely sensed data. Remote Sens. Environ. 2007, 109, 314-327.

18. Davidson, E.A.; Asner, G.P.; Stone, T.A.; Neill, C.; Figueiredo, R.O. Objective indicators of pasture degradation from spectral mixture analysis of Landsat imagery. J. Geophys. Res. 2008, doi: 10.1029/2007JG000622.

19. Ministério do Meio Ambiente (MMA). Mapeamento da Cobertura Vegetal do Bioma Cerrado. Relatório Final; Edital Probio 02/2004, Projeto Executivo B.02.02.109; Embrapa Cerrados: Planaltina, Brazil, 2007.

20. Costa, M.H.; Botta, A.; Cardille, J.A. Effects of large-scale changes in land cover on the discharge of the Tocantins river, Southeastern Amazonia. J. Hydrol. 2007, 283, 206-217.

21. Ferreira, L.G.; Asner, G.P.; Knapp, D.E.; Davidson, E.A.; Coe, M.; Bustamante, M.M.C.; Oliveira, E.L. Equivalent water thickness in savanna ecosystems: MODIS estimates based on ground and EO-1 Hyperion data. Int. J. Remote Sens. 2011, 111, 1-18.

22. Coe, M.; Latrubesse, E.M.; Ferreira, M.E.; Amsler, M.L. The effects of deforestation and climate variability on the streamflow of the Araguaia River, Brazil. Biogeochemistry 2011, 105, 119-131.

23. Costa, M.H.; Pires, G.F. Effects of Amazon and central Brazil deforestation scenarios on the duration of the dry season in the arc of deforestation. Int. J. Climatol. 2009, doi:10.1002/joc.2048. 
24. Malhado, A.C.M.; Pires, G.F.; Costa, M.H. Cerrado conservation is essential to protect the Amazon rainforest. Ambio 2010, 39, 580-584.

25. Caselles, V.; Lopéz-García, M.J. An alternative simple approach to estimate atmospheric correction in multitemporal studies. Int. J. Remote Sens. 1989, 10, 1127-1134.

26. Tanre, D.; Holben, B.N.; Kaufman, Y.J. Atmospheric correction algorithm for NOAA-AVHRR products: Theory and application. IEEE Trans. Geosci. Remote Sens. 1992, 30, 231-248.

27. Huete, A.R.; Didan, K.; Miura, T.; Rodriguez, E.P.; Gao, X.; Ferreira, L.G. Overview of the radiometric and biophysical performance of the MODIS vegetation indices. Remote Sens. Environ. 2002, 83, 195-213.

28. Jiang, Z.; Huete, A.R.; Didan, K.; Miura, T. Development of a two-band enhanced vegetation index without a blue band. Remote Sens. Environ. 2008, 112, 3833-3845.

29. Solano, R.; Didan, K.; Jacobson, A.; Huete, A.R. MODIS Vegetation Indices (MOD13) User's Guide; 2010. Available online: http://tbrs.arizona.edu/project/MODIS/MOD13.C5-UsersGuide-HTML-v1.00 (accessed on 25 February 2011).

30. Rojas, F.; Schowengerdt, R.A.; Biggar, S.F. Early results on the characterization of the Terra MODIS spatial response. Remote Sens. Environ. 2002, 83, 50-61.

31. Schowengerdt, R.A. Remote Sensing, Models and Methods for Image Processing; Elsevier: San Diego, CA, USA, 2007.

32. Oki, T.; Kanae, S. Global hydrological cycles and world water resources. Science 2006, 313, 1068-1072.

33. Kummerow, C.; Barnes, W.; Kozu, T.; Shiue, J.; Simpson, J. The Tropical Rainfall Measuring Mission (TRMM) sensor package. J. Atmos. Oceanic Technol. 1998, 15, 809-817.

34. Mu, Q.; Zhao, M.; Running, S.W. Improvements to a MODIS global terrestrial evapotranspiration algorithm. Remote Sens. Environ. 2011, 115, 1781-1800.

35. Ferreira, L.G.; Yoshioka, H.; Huete, A.R.; Sano, E.E. Seasonal landscape and spectral vegetation index dynamics in the Brazilian Cerrado: An analysis within the Large Scale Biosphere-Atmosphere Experiment in Amazonia (LBA). Remote Sens. Environ. 2003, 87, 534-550.

36. WMO. WMO statement on the status of the global climate in 2010. World Meteorol. 2011, 1074, $1-15$.

37. Sano, E.E.; Barcellos, A.O.; Bezerra, H.S. Assessing the spatial distribution of cultivated pastures in the Brazilian savanna. Pasturas Tropicales 2000, 22, 2-15.

38. Oliveira, O.C.; Oliveira, I.P.; Alves, B.J.R.; Urquiaga, S.; Boddey, R.M. Chemical and biological indicators of decline/degradation of Brachiaria pastures in the Brazilian Cerrado. Agr. Ecosyst. Environ. 2004, 103, 289-300.

39. Paruelo, J.M.; Lauenroth, W.K. Regional patterns of Normalized Difference Vegetation Index in North American shrublands and grasslands. Ecology 1995, 76, 1888-1898.

40. Psomas, A.; Kneubühler, M.; Huber, S.; Itten, K.; Zimmermann, N.E. Hyperspectral remote sensing for estimating aboveground biomass and for exploring species richness patterns of grassland habitats. Int. J. Remote Sens. 2011, 32, 9007-9031.

41. Hobbs, R.J.; Huenneke, L.F. Disturbance, diversity, and invasion: Implications for conservation. Conserv. Biol. 1992, 6, 324-337. 
42. Verburg, P.H.; van de Steeg, J.; Veldkamp, A.; Willemen, L. From land cover change to land function dynamics: A major challenge to improve land characterization. J. Environ. Manage. 2009, 90, 1327-1335.

43. Obata, K.; Wada, T.; Miura, T.; Yoshioka, H. Scaling effect of area-averaged NDVI: Monotonicity along the spatial resolution. Remote Sens. 2012, 4, 160-179.

44. Edirisinghe, A.; Hill, M.J.; Donald, G.E.; Hyder, M. Quantitative mapping of pasture biomass using satellite imagery. Int. J. Remote Sens. 2011, 32, 2699-2724.

45. Garbulsky, M.F.; Peñuelas, J.; Gamon, J.; Inoue, Y.; Filella, I. The photochemical reflectance index (PRI) and the remote sensing of leaf, canopy and ecosystem radiation use efficiencies: A review and meta-analysis. Remote Sens. Environ. 2011, 115, 281-297.

46. Seastedt, T.R.; Knapp, A.K. Consequences of non-equilibrium resource availability across multiple time scales: the transient maxima hypothesis. Amer. Nat. 1993, 141, 621-633.

47. Zoneamento Agroecológico da Cana-de-Açúcar. EMBRAPA, 2009 (Brasília). Available online: http://www.cnps.embrapa.br/zoneamento_cana_de_acucar/ZonCana.pdf (accessed on 15 January 2013).

48. Martinelli, L.A.; Filoso, S. Expansion of sugarcane ethanol production in Brazil: Environmental and social challenges. Ecol. Appl. 2008, 18, 885-898.

49. Sawyer, D. Climate change, biofuels and eco-social impacts in the Brazilian Amazon and Cerrado. Philos. Trans. Roy. Soc. Biol. Sci. 2008, 363, 1747-1752.

(C) 2013 by the authors; licensee MDPI, Basel, Switzerland. This article is an open access article distributed under the terms and conditions of the Creative Commons Attribution license (http://creativecommons.org/licenses/by/3.0/). 